\title{
GROWTH AND YIELD OF SOYBEAN WITH PENERGETIC APPLICATION
}

\author{
Efeito da aplicação Penergetic no crescimento e produtividade da soja
}

Adriano Aparecido de Souza ${ }^{1}$; Fábio Zanuto de Almeida ${ }^{1}$; Odair Alberton ${ }^{2 *}$

\begin{abstract}
${ }^{1}$ Discentes do Curso em Engenharia Agronômica da Universidade Paranaense - UNIPAR, Umuarama - PR.
${ }^{2}$ Programa de pós-graduação em Biotecnologia Aplicada à Agricultura. Universidade Paranaense - UNIPAR, Umuarama - PR. E-mail: odair@prof.unipar.br ou oalberton@yahoo.com.br (*autor para correspondência).
\end{abstract}

Artigo enviado em 30/05/2017, aceito em 02/09/2017 e publicado em 20/12/2017.

\begin{abstract}
Soybean (Glycine max L.) plants are economically important for food industry and animal feed due their nutritional qualities. Soybean crops are highly productive and responsive to new technologies, such as, Penergetic. The aim of this study was to assess the effect of Penergetic-P and Penergetic-K on soybean growth and yield. The Penergetic products were tested according to five different treatments in the field: 1-) control (without NPK and/or Penergetic); 2-) $290 \mathrm{~kg} \mathrm{ha}^{-1}$ NPK (04-24-18) + Micro; 3-) $300 \mathrm{~g} \mathrm{ha}^{-1}$ Penergetic-P + $290 \mathrm{~kg} \mathrm{ha}^{-1}$ NPK (04-24-18) + Sulfate (S); 4-) $300 \mathrm{~g} \mathrm{ha}{ }^{-}$ 1 of Penergetic-K; 5-) $300 \mathrm{~g} \mathrm{ha}^{-1}$ Penergetic-P $+300 \mathrm{~g} \mathrm{ha}^{-1}$ Penergetic-K. The experiment was conducted in a randomized block design, with three replications for each treatment. Comparisons were performed by ANOVA and Duncan test $(\mathrm{p} \leq$ 0.05). Differences among treatments for number of nodules per plant were not significant, but observed for dry weight of nodules (DWN). Application of Penergetic-K in soil increased the DWN in comparison with application of NPK and micronutrients. Shoot, root, total dry matter and shoot/root ratio did not differ among treatments as well as the chlorophyll index and nitrogen in shoots. The grain yield was lower with the addition of NPK + micronutrients and higher with the addition of Penergetic-K. Penergetic-K addition increased soybean yield, up to $20 \%$ compared to the treatment with NPK + micronutrients. We conclude that the use of Penergetic benefits the soybean production.
\end{abstract}

Keywords - Bio-activator of soil, nutrients, sustainability

Resumo - A soja (Glycine max L.) tem grande importância comercial, pois é extensivamente utilizado como alimento humano ou ração animal, devido às qualidades nutricionais. Tem um alto potencial produtivo e bastante responsivo á tecnologia, como Penergetic. O objetivo deste estudo foi estudar a resposta da adição de Penergetic-P e de Penergetic-K no crescimento e na produtividade da soja. Foram (conduzidos cinco tratamentos no campo: 1-) controle (sem NPK e/ou Penergetic); 2-) $290 \mathrm{~kg} \mathrm{ha}^{-1}$ NPK (04-24-18) + Micro; 3-) $300 \mathrm{~g} \mathrm{ha}^{-1}$ de Penergetic-P + $290 \mathrm{~kg} \mathrm{ha}^{-1}$ NPK (04-24-18) + sulfato (S); 4-) $300 \mathrm{~g} \mathrm{ha}^{-1}$ de Penergetic-K; 5-) $300 \mathrm{~g} \mathrm{ha}^{-1}$ de Penergetic-P + $300 \mathrm{~g} \mathrm{ha}^{-1}$ Penergetic-K. O delineamento experimental foi em blocos casualizados com 3 repetições. As médias foram comparadas usando a ANOVA e o teste de Duncan $(\mathrm{p} \leq 0,05)$. Não foi observada diferença significativa no NNP entre os tratamentos, porém, a massa seca dos nódulos (MSN) teve diferença significativa entre os tratamentos, sendo que a adição Penergetic-K no solo aumentou a MSN em relação à adição de somente NPK e micronutrientes. A produção de massa seca raízes (MSR), massa seca parte aérea (MSPA), massa seca total, relação MSPA/MSR, o índice de clorofila, nitrogênio da parte aérea não teve diferença significativa entre os tratamentos. A produtividade de grãos foi menor com a adição de NPK e micronutrientes e foi aumentada com a adição de Penergetic-K. A utilização do Penergetic-K proporcionou um incremento na produtividade da soja, com aumento de até $20 \%$ em relação à adição de somente NPK+micronutrientes ao solo. Concluiu-se que a utilização do Penergetic traz resultados positivos e benefícios na produção de soja.

Palavras-Chave - Bioativador do solo, nutrientes, sustentabilidade.

\section{INTRODUCTION}

Soybean (Glycine max L. Merrill) is one of the most important crops in the global economy. It is also one of the most studied plants in the world due to the high nutritional value of its grains, largely used in the food and animal feed industries and as raw matter for manufacturing. By
2016/2017, the Brazilian soybean crops covered about 34 million hectares of arable lands, representing a production of 110 million tons of grain at an average yield of $3362 \mathrm{~kg}$ $\mathrm{ha}^{-1}$, what placed Brazil as the world's second largest producer of this commodity (BRASIL, 2017).

In order to keep or increase the soybean high yields, technologies have been adopted to improve production 
systems. They include soil management, breeding techniques, biological control, biological nitrogen fixation, integrated pest and disease management and the use of soil bio-activators, as the Penergetic technology (BRITO et al., 2012).

Penergetic technics allows the transference of active processes from a source substance to a carrier substance. Such active processes intensify and accelerate biological activities in soil cropping systems and in plant photosynthesis (BRITO et al., 2012). The Penergetic technology doesn't replace macro and micro fertilization but complements the nutrition required by the soybean crop by improving the uptake of nutrients immobilized in soils. The Penergetic technology accelerates the organic matter mineralization, making available on soil solution those nutrients previously immobilized on organic matter (NASCENTE \& COBUCCI, 2014; PENERGETIC, 2016).

Penergetic-K is a soil bio-activator that triggers mineralization and metabolism of the soil biomass. It accelerates the organic matter decomposition, increasing the availability of nutrients for achieving more productive and sustainable agroecosystems (BRITO et al., 2012). Penergetic-P is a plant bio-activator with effect on the photosynthetic process, enabling an extra energy for a highly-efficient photosynthesis (BRITO et al., 2012; PENERGETIC, 2016). The Penergetic technology combines products that activate the soil biomass to make phosphorous available to plants.

Appropriate mineral nutrition obtained from good farming practices of soil management and fertilization is essential to make high yields in economically viable way. Soybean is one of the Brazilian crops that better adapt to no tillage (NT) systems. Highly efficient in biological nitrogen fixation (BNF), the soybean also composes systems of rotation and integration between crop and livestock (HUNGRIA et al., 2015).

Farming activities are subjected to climate variations, the main reason for farmers not attaining the maximum yield potential of their crops (OLIVEIRA et al., 2013). According to Neumaier et al. (2000), long drought periods followed by water shortage reduce the plant height, the relative growth rate, the leaf area index and the photosynthesis rate. On this way, it is expected a reduced grain production, as a result of slower metabolism.

Phosphate fertilizers are applied in large amounts in Brazilian soils, although the $\mathrm{P}$ uptake rate by crops is lower than those of nitrogen and potassium. This is because phosphorous is strongly fixed at clays; thus the efficiency of phosphorus fertilization is low, especially in those high acidity conditions in which Brazilian soils are found (FAQUIN, 1994).

The aim of this study was to assess the effect of Penergetic- $\mathrm{P}$ and Penergetic-K on soybean growth and yield.

\section{MATERIAL AND METHODS}

The study was carried out in the São João ranch, at the Rancho Alegre D’Oeste city, Paraná, Brazil; at coordinates S $24^{\circ} 21^{\prime} 243^{\prime}$ and WO $53^{\circ} 00^{\prime} 117^{\prime}$ and at $455 \mathrm{~m}$ altitude. The soil type was Dystrophic Red Latosol (Embrapa, 2013) of clay texture (60\% clay), typically found in slightly flat topography. The chemical and physical analysis of soil was taken by the Santa Rita Mamborê laboratory (Table 1), in Paraná, Brazil.

The experiment was conducted at open field conditions, in a complete randomized block design with five treatments and three replications (blocks). Experimental unit was scaled to $4.05 \mathrm{~m}$ wide and $5 \mathrm{~m}$ long, totaling 20.25 $\mathrm{m}^{2}$ each. BRS-284 was the conventional variety used in notillage system on oat straw. Plant density was $26 \mathrm{~m}^{-2}$ and the spacing between rows was $0.45 \mathrm{~m}$, totalizing a population of 260,000 plants $\mathrm{ha}^{-1}$. All seeds were treated with fungicide and insecticide and inoculated with Bradyrbizobium before sowing, as technical recommendations for this crop.

Penergetic products were applied according to five different treatments: 1-) control (without fertilizer NPK and/or Penergetic); 2-) $290 \mathrm{~kg} \mathrm{ha}^{-1} \mathrm{NPK}$ (04-24-18) + Micro; 3-) $300 \mathrm{~g} \mathrm{ha}^{-1}$ Penergetic-P + $290 \mathrm{~kg} \mathrm{ha}^{-1}$ NPK (0424-18) + Sulfate (S); 4-) $300 \mathrm{~g} \mathrm{ha}^{-1}$ of Penergetic-K; 5-) 300 $\mathrm{g} \mathrm{ha}^{-1}$ Penergetic-P $+300 \mathrm{~g} \mathrm{ha}^{-1}$ Penergetic-K.

Penergetic-K was applied in post-sowing and the Penergetic-P was divided into three foliar applications, made with a backpack sprayer. The pest and disease control was made in all treatments as required. The experiment lasted 125 days, referring to the cycle of the BRS-284 variety.

At the $45^{\text {th }}$ day post emergence, chlorophyll index was measured at morning. Indirect measure of the chlorophyll values were carried out by a portable chlorophyll meter (ClorofiLOG ${ }^{\circledR}$ CFL 1030), operating according to the manufacturer's instructions (FALKER, 2008).

Chlorophyll index of 5 completely developed leaves per plant was taken for each treatment, in a randomized way. In sequence, plants were harvested and sectioned into shoot and root. Plant heights $(\mathrm{cm})$ were obtained with a tape measure and then plants were dried in an oven at $65^{\circ} \mathrm{C}$ until constant weight. Then, plant parts were weighted in a semi-analytical balance to determine the dry weight of nodules (DWN), root (DWR), shoot (DWS) and total (DWT). Number of nodules (NN) was also determined.

Subsequently, shoot was ground to determine the level of $\mathrm{N}$ in the shoot (NS) with sulfuric acid digestion, followed by distillation according to the Kjeldahl method, as described by Silva (2009).

Plants were harvested for grain yield estimation, 120 days after sowing. The material surrounding $1 \mathrm{~m}^{2}$ of each plot was discarded in order to avoid interference among treatments in the analysis. Ten plants were harvested per treatment. Among them, three to four plants were collected per block. Then, the number of pods per plant (NPP) was counted and averaged by treatment to estimate the grain yield, from the manually threshed pods.

The estimate grain yield (sacks ha-1) was obtained by the average grain weight of 10 plants multiplied by the number of plants per hectare.

Data were subjected to ANOVA and means were compared by Duncan test $(p \leq 0.05)$, using the SPSS software version 22.0 for Windows (SPSS Inc., Chicago, IL, USA). 


\section{RESULTS AND DISCUSSION}

Nutrient levels observed in this study followed the levels recommended for the soybean crop (Table1), with exception of potassium $(K)$ that presented levels lower than those indicated by the manual of soybean fertilization and liming, stated for Paraná, Brazil (SBCS/NEAR, 2017).

Table 1. Chemical and physical properties of the soil in the experimental area.

\begin{tabular}{|c|c|c|c|c|c|c|c|c|c|c|c|c|}
\hline $\mathrm{pH}$ & $\mathrm{P}$ & $\mathrm{OM}$ & $\mathrm{Al}^{3+}$ & $\mathrm{H}^{+}+\mathrm{Al}^{3+}$ & $\mathrm{Ca}^{2+}$ & $\mathrm{Mg}^{2+}$ & $\mathrm{K}^{+}$ & CEC & $\mathrm{V}$ & Sand & Silt & Clay \\
\hline$\left(\mathrm{CaCl}_{2}\right)$ & $\mathrm{mg} \mathrm{dm}-3$ & $\mathrm{~g} \mathrm{dm}^{-3}$ & \multicolumn{6}{|c|}{-- } & \multicolumn{4}{|c|}{---------------\%o-------------- } \\
\hline 5.60 & 23.48 & 3.57 & 0.00 & 4.96 & 8.95 & 2.95 & 0.58 & 12.49 & 71.57 & 20.0 & 20.0 & 60.0 \\
\hline
\end{tabular}

Differences were not significant among treatments for NN. However, they were for DWN (Table 2). Application of Penergetic-K in soil increased the DWN in comparison with the application of NPK and micronutrients (Table 2). Penergetic- $\mathrm{K}$ increases nutrient availability in soils, via biological activation. Thus, accelerates mineralization of organic matter and delivers previously unavailable macronutrients $(\mathrm{N}, \mathrm{P}$ and $\mathrm{K})$ to soil solution (BRITO et al., 2012; PENERGETIC, 2016). The application of NPK decreased DWN and as a result, probably affected the BNF. According to Hungria et al. (2015), the use of nitrogen fertilization in fabaceae has adverse effect on the BNF, by decreasing availability of $\mathrm{O}_{2}$ for nodular respiration, reducing DWN. This could be the case in the present study.

DWR, DWS, DW'T and the DWR/DWS ratio did not differ among treatments (Table 2), as well as chlorophyll index, level of $\mathrm{N}$ in shoots (NS) and number of pods per plant (NPP) (Table 3).

Plant heights were lower in control treatment (Table 3). It indicates that addition of Penergetic and/or NPK for growing soybean plants alters the yield at the end of the crop cycle.

Table 2. Values of $P$ in ANOVA* of number of nodules (NN), dry weight of nodules (DWN - g), dry weight of root (DWR g), dry weight of shoot (DWS - g), total dry weight (DWT - g) and DWS/DWR ratio.

\begin{tabular}{lllllll}
\hline Treatments & NN & DWN & DWR & DWS & DWT \\
\hline $1-$ Control & $38.0 \pm 5.2$ & $0.23 \pm 0.03 \mathrm{ab}$ & $1.87 \pm 0.21$ & $12.14 \pm 1.31$ & $14.02 \pm 1.50$ & $6.76 \pm 0.38$ \\
$2-$ NPKmicro & $36.2 \pm 4.3$ & $0.17 \pm 0.02 \mathrm{~b}$ & $1.84 \pm 0.16$ & $12.64 \pm 1.11$ & $14.47 \pm 1.26$ \\
$3-$ PePNPKMicro & $35.6 \pm 2.3$ & $0.21 \pm 0.02 \mathrm{ab}$ & $2.04 \pm 0.15$ & $13.35 \pm 1.13$ & $15.39 \pm 1.27$ \\
$4-$ PeK & $45.2 \pm 5.2$ & $0.28 \pm 0.02 \mathrm{a}$ & $1.94 \pm 0.14$ & $12.71 \pm 1.05$ & $14.65 \pm 1.18$ & $6.91 \pm 0.20$ \\
$5-$ PePK & $47.4 \pm 5.4$ & $0.23 \pm 0.03 \mathrm{ab}$ & $1.82 \pm 0.15$ & $12.79 \pm 0.64$ & $14.61 \pm 0.77$ & $7.54 \pm 0.26$ \\
\hline Values of $P$ & 0.262 & $\mathbf{0 . 0 4 6}$ & 0.870 & 0.956 & 0.955 & 0.390 \\
\hline
\end{tabular}

1-) control (without NPK and/or Penergetic); 2-) $290 \mathrm{~kg} \mathrm{ha}^{-1}$ NPK (04-24-18) + Micro; 3-) $300 \mathrm{~g} \mathrm{ha}^{-1}$ Penergetic-P + 290 kg ha ${ }^{-1}$ NPK (04-24-18) +

Sulfate (S); 4-) $300 \mathrm{~g} \mathrm{ha}^{-1}$ of Penergetic-K; 5-) $300 \mathrm{~g} \mathrm{ha}^{-1}$ Penergetic-P + $300 \mathrm{~g} \mathrm{ha}^{-1}$ Penergetic-K.

$*$ Mean values ( $\mathrm{n}=10 \pm$ standard error); different letters in the same column differ significantly by the Duncan test $(p \leq 0.05)$.

Grain weight per plant (GWP) and grain yield were lower for treatments with NPK and micronutrients and higher for Penergetic-K treatments (Table 3). The same was observed for the DWN (Table 2), demonstrating the importance of $\mathrm{BNF}$ to increase grain yield. Inoculation with Bradyrbizobium is essential to soybean. The efficiency of these bacteria has enabled high grain yields without relying on mineral nitrogen (ALVES et al., 2003; HUNGRIA et al., 2015). Phosphorous fertilization provides the development of nodules and also proper performance (SÁ \& ISRAEL, 1991). Pekarkas et al. (2011) observed that Penergetic-K increased significantly soil $\mathrm{pH}$ and consequently affected availability of some nutrients.

In Brazilian soils, phosphorous is normally fixed by iron and aluminum hydroxides, restricting its absorption by plant root systems (MALAVOLTA, 2006). Phosphorous shortage in soil solution can negatively affect BNF in soybean (ALVES et al., 2003). Therefore, phosphorous fertilization in soybean crops is crucial to obtain high yields.
Furthermore, use of Penergetic may contribute to soybean nutrition, as observed by the increased weight of nodules found in this study

A study by Nascente \& Cobucci (2014), related that application of Penergetic, regardless of the combination with phosphorous doses, increased grain yield of common.

Studies about the use of the Penergetic bio-activator in soybean are rare in literature. This is the first investigation that proves the efficiency of the Penergetic as a stimulus for BNF through an increased DWN, plant growth and productivity. Few studies on Penergetic were published once this technology is recent. However, Pekarkas et al. (2011) observed an expressive increase of $12.17 \%$ in the wheat yield and an increase of $19.9 \%$ in the gluten level with the use of Penergetic. Similar results were found in this study, in which an increase of $20 \%$ on soybean yield was observed. 
Table 3. Values of $P$ in ANOVA* of plant height $(\mathrm{cm})$, chlorophyll index (CI), shoot $\mathbf{N}$ content (NS - $\left.\mathrm{mg} \mathrm{kg}^{-1}\right)$, number of pods per plant (NPP), grain weight per plant (GMP - g) and grain yield (sacks ha-1).

\begin{tabular}{lllllll}
\hline Treatments & Height & CI & NS & NPP & GWP & Grain yield \\
\hline 1 - Control & $72.6 \pm 0.62 \mathrm{c}$ & $39.96 \pm 0.61$ & $34.12 \pm 1.10$ & $68.9 \pm 5.8$ & $21.66 \pm 0.57 \mathrm{bc}$ & $93.4 \pm 0.5 \mathrm{c}$ \\
$2-$ NPKmicro & $83.3 \pm 1.38 \mathrm{ab}$ & $39.01 \pm 0.97$ & $35.16 \pm 1.53$ & $56.1 \pm 3.7$ & $19.75 \pm 0.33 \mathrm{~d}$ & $85.4 \pm 0.3 \mathrm{e}$ \\
$3-$ PePNPKMicro & $84.2 \pm 1.05 \mathrm{a}$ & $40.74 \pm 0.72$ & $36.65 \pm 0.94$ & $64.5 \pm 5.1$ & $22.68 \pm 0.39 \mathrm{ab}$ & $98.1 \pm 0.4 \mathrm{~b}$ \\
$4-$ PeK & $78.7 \pm 1.71 \mathrm{~b}$ & $38.29 \pm 0.96$ & $36.47 \pm 0.93$ & $72.1 \pm 5.5$ & $23.80 \pm 0.33 \mathrm{a}$ & $103.1 \pm 0.5 \mathrm{a}$ \\
$5-$ PePK & $80.4 \pm 1.33 \mathrm{ab}$ & $40.64 \pm 0.79$ & $36.85 \pm 0.75$ & $66.7 \pm 5.4$ & $21.10 \pm 0.32 \mathrm{c}$ & $91.4 \pm 0.3 \mathrm{~d}$ \\
\hline Values of $P$ & $<\mathbf{0 . 0 0 1}$ & 0.177 & 0.178 & 0.266 & $<\mathbf{0 . 0 0 1}$ & $<\mathbf{0 . 0 0 1}$ \\
\hline *Mean values (n = 10 \pm standard error); different letters in the same column differ sionificantly by the Duncan test $(p \leq 0.05)$. &
\end{tabular}

It is necessary further studies, since farmers are using these products and reporting positive increments in grain yields, as evidenced in this study. It is also worth mentioning the increased plant nutrition and soil microbial activity observed in our results.

\section{CONCLUSION}

It was concluded that addition of Penergetic in soybean did not affect the plant growth. However, grain weight per plant and yield of soybean were higher with Penergetic-K addition to the soil in comparison with the application of fertilizer NPK and micronutrients.

\section{ACKNOWLEDGEMENTS}

Authors acknowledge UNIPAR for the financial support. Odair Alberton acknowledges a research fellowship from CNPq (National Council for Scientific and Technological Development).

\section{REFERENCES}

ALVES, B. J.; BODDEY, R. M.; URQUIAGA, S. The success of BNF in soybean in Brazil. Plant soil. v. 252, p. 19, 2003.

BRITO, O. R.; DEQUECH, F. K.; BRITO, R. M. Use of penergetic procucts $\mathrm{P}$ and $\mathrm{K}$ in snap bean production. Annual report of the bean improvement cooperative. v. 55, p. 279280, 2012.

BRASIL - Instituto Brasileiro de Geografia e Estatística (IBGE). Conjuntura Agrícola. Disponível em: http://www.ibge.gov.br/Producao_Agricola/Fasciculo...I BGE/estProdAgr_201702.pdf. 27 - 07 - 2017.

EMPRESA BRASILEIRA DE PESQUISA AGROPECUÁRIA - EMBRAPA. Centro Nacional de Pesquisa de Solos. Sistema brasileiro de classificação de solos. 3. ed. Brasília. 353 p. 2013.

FALKER. Automação Agrícola Ltda. Manual do medidor eletrônico de teor clorofila (ClorofiLOG/CFL 1030). Porto Alegre, Falker Automação Agrícola. 2008.

FAQUIN, V. Nutrição mineral de plantas. Lavras: ESALQ/FAEPE. 227 p. 1994.
HUNGRIA, M.; NOGUEIRA, M.; ARAÚJO, R. Soybean seed co-inoculation with Bradyrbizobium spp. and Azospirillum brasilense: A new biotechnological tool to improve yield and sustainability. American Journal of Plant Sciences. v. 6, p. 811-817, 2015.

MALAVOLTA, E. Manual de nutrição de plantas. São Paulo, Ceres, 638 p. 2006.

NASCENTE, A. S.; COBUCCI, T. Phosphate fertilization in the soil and penergetic application in the grain yield of common bean. The 20th World Congress of Soil Science. Jeju, Korea. 1 p. 2014.

NEUMAIER, N.; NEPOMUCENO, A. L.; FARIAS, J. R. B.; OYA, T. Estresses de ordem ecofisiológica. In: Bonato, E. R. (Ed.). Estresses em soja. Passo Fundo: Embrapa Trigo, 254 p. 2000.

OLIVEIRA, P.; NASCENTE, A. S.; KLUTHCOUSKI, J. Soybean growth and yield under cover crops. Revista Ceres. v. 60 , p. $249-256,2013$.

PEKARSKAS, J.; VILKENYTE, L.; SILEIKIENE, D.; CESONIENE, L.; MAKARENKO, N. Effect of organic nitrogen fertilizers provita and fermentador penergetic- $K$ winter wheat and soil quality. Lithuania. Vilnius Gediminas Technical University, $8^{\text {th }}$ International Conference on Environmental Engineering. p. 248-254, 2011.

PENERGETIC DO BRASIL. Disponível em: http://www.penergetic.com.br. 13 - 07 - 2016.

SÁ, T. M.; ISRAEL, D. W. Energy status and functioning of phosphorus-deficient soybean nodules. Plant Physiology. v. 97, p. 928-935, 1991.

SBCS/NEAR - Sociedade Brasileira de Ciência do Solo/Núcleo Estadual Paraná. Manual de adubação e calagem para o estado do Paraná. $1^{\text {a }}$ ed. Curitiba. SBCS/NEAR, 482 p. 2017.

SILVA, C. F. Manual de análises químicas de Solos, plantas e fertilizantes. 2 ed. Brasília DF: Embrapa. 627 p. 2009. 